\title{
Anti-Pathogenic Activity of Herbs Used in Argentinean Traditional Infusion
}

\author{
I. Y. Brodkiewicz' ${ }^{1}$ R. D. I. Molina ${ }^{2}$, G. Vega Lopez ${ }^{1}$, M. R. Alberto ${ }^{2}$, N. R. Vera ${ }^{1}$ and \\ M. E. Arena ${ }^{1,2, *}$
}

${ }^{1}$ Facultad de Bioquímica, Química y Farmacia, Universidad Nacional de Tucumán (UNT), Ayacucho 471, 4000, San Miguel de Tucumán, Argentina

${ }^{2}$ Instituto de Biotecnología Farmacéutica y Alimentaria (INBIOFAL-CONICET), Argentina. Av. Kirchner 1900, Tucumán, 4000, Argentina

\begin{abstract}
The anti-pathogenic activity of Acantholippia deserticola, Haplopappus baylahuen, Lippia integrifolia and Satureja parvifolia herbs used as traditional infusion was investigated. The extracts obtained were compared with respect to chromatographic profiles and antimicrobial activities. The dichloromethane and methanol extracts of the four herbs showed significant inhibition of Staphylococcus aureus and Pseudomonas aeruginosa growth and biofilm formation. The dichloromethane extract of Lippia integrifolia that showed the highest inhibitory effect on $P$. aeruginosa biofilm formation, was fractionated by column chromatography using a gradient of polarity, and the activities of the fractions were evaluated. In general, the lower polar fractions inhibited biofilm in correlation with bacterial growth. However, in more polar fractions the biofilm diminution is well correlated with the inhibition of autoinducers production more than the bacterial development. The results provide scientific support for the usage of these herbs to the protection against foodborne diseases. This effect is noteworthy in L. integrifolia because the fractions showed higher growth, biofilm, and autoinducer inhibitory activity than the crude extract.
\end{abstract}

Keywords: Traditional infusions, South American herbs, Biofilm inhibition, Anti-pathogenic activity, Lippia integrifolia.

\section{INTRODUCTION}

People from many South American countries use to consume a traditional beverage called "mate" (drink prepared as an infusion of Ilex paraguariensis leaves and twigs, commonly named "yerba mate"). It is prepared in a very sui generis way by large populations in South America, having evolved from a tea drunk by the Guarani ethnic group to a beverage that has a social and almost ritualistic role in some South American modern societies [1, 2]. In fact, it was informed as the most commercialized plant of South America [3].

The mate is an infusion that is consumed by sucking a straw or bulb, which is shared by a group of people. Once the infusion is ready, a special drinking straw, "bombilla" (literally: small pump) is usually made of metals such as stainless steel that "bombilla" which finish in a closed perforated bulblike filter is inserted into the mate [4]. This bulb has perforations, which are the size of a pinhole; avoid the aspiration of fine solids powdered mate leaves when the infusion is sucked up through it. This peculiar method of brewing allows for a continuous extraction of the compounds in the dried leaves, indeed, a portion of the compacted tea is left dry on top.

${ }^{*}$ Address correspondence to this author at the Av Kirchner 1900 Tucuman CP 4000; Tel/Fax: 0054-0381 4248169; Email: arename@fbqf.unt.edu.ar
Each extract of about $30 \mathrm{ml}$ is drunk by a person. After that, the mate is filled and served to anotherperson. Many people consume between 1-2 liters per day. Therefore, the risk of microbial infection is high $[5,6]$. For this reason, the use of herbs that may have antimicrobial properties is important from a hygienic-sanitary point of view. Populations of Northern Argentina add different herbs to the "mate" because they traditionally attribute medicinal properties to these herbs. Acantholippia deserticola, Haplopappus baylahuen, Lippia integrifolia and Satureja parvifolia are the four very popular herbs added to the mate infusion [7]. Acantholippia deserticola (Phil.) Moldencke is a small bush, commonly known as rica-rica, this herb is used in herbal medicine for diarrhea, gastrointestinal bloating, dyspepsia and by treating liver disorders, and digestive complaints [8]. Haplopappus baylahuen Remy (Asteraceae) known as Baila bien and its aerial parts are widely used for its liver stimulating properties [9]. Lippia integrifolia (Gris.) Hieronymus (Verbenaceae) is a woody aromatic shrub, known as Incayuyo, and it is used for gastrointestinal disorder and has been included in the Argentina Food Code [10]. Satureja parvifolia (Phil.) Epling, the synonym of Clinopodium gilliesii (Benth Kuntze) is a species growing in the Andean countries, popularly known as "Muña-Muña", used in food as an aromatic plant, but also in traditional medicine [11].

(C) 2017 Avanti Publishers 
Due to the risk of foodborne disease and the low people infected due to mate consumption, we investigated the properties of these herbs to control the growth and biofilm formation in a Gram-negative and a Gram-positive bacterium.

Several foodborne disease outbreaks have been associated with microbial biofilm [12]. The biofilm formation is regulated by the bacteria cells-cells communication called Quorum sensing (QS), mediated by small diffusible signal molecules called autoinducers (Al). Gram negative bacteria produce $\mathrm{N}$-acylhomoserine lactones (AHLs) as QS molecules [13] and several AHLs had been found in food [14]. Moreover, the bacterial signal molecules per se may influence the outcome of an infection by modulating the host immune response [15]. Pseudomonas sp. is one of the main biofilm producing bacteria found in food.

On the other hand, Staphylococcal foodborne intoxication is reported to be one of the most common bacterial foodborne diseases in several countries and the food processing promotes biofilm formation by Staphylococcus aureus [16].

The inhibitory potential of Northern Argentina herbs extracts on the growth and biofilm formation by $S$. aureus and $P$. aeruginosa strains, as well as, on the production of $\mathrm{N}$-acyl-homoserine lactones (AHLs) by $P$. aeruginosa was evaluated.

\section{MATERIALS AND METHODS}

\subsection{Plant Material}

Four dried herbs including Acantholippia deserticola, Haplopappus baylahuen, Lippia integrifolia and Satureja parvifolia were purchased from local herbalism's of San Salvador de Jujuy (Jujuy, Argentina) and San Miguel de Tucuman (Tucuman, Argentina).

\subsection{Preparation of Plant Extracts}

Dried plant material $(200 \mathrm{~g})$ for each species was extracted by soaking, first in dichloromethane (DCM) $(200 \mathrm{ml})$ and after that in methanol $(\mathrm{MeOH})(200 \mathrm{ml})$ at room temperature for 7 days with each solvent, with discontinuous agitation and then vacuum filtered. Both extracts were dried by a rotary evaporator until $45^{\circ} \mathrm{C}$. The weight of dried extracts represented the extracted material for each extract. Extracts were stored at $-20^{\circ} \mathrm{C}$ until use.

\subsection{Thin Layer Chromatography (TLC) of Extracts}

All extracts were loaded onto analytical TLC plates (Silica gel $60 \mathrm{~F}_{254}, 3.5 \times 7 \mathrm{~cm}$, Merck), and developed using ethyl acetate/chloroform (EA:C, 4:1, v/v) as the mobile phase. After drying, bands were located by viewing under short (254 nm) and long (366 nm) UV radiation. The following sprays were used to locate the bands on the TLC: Godin reagent (1 vol $1 \%$ vanillin in ethanol +1 vol $3 \%$ perchloric acid in water) and heating to $85^{\circ} \mathrm{C}$ for $5 \mathrm{~min}$ was used for reveal polyols, phenols, and ketones [17] (Godin, 1954) and LiebermanBouchard reagent (LB) was used for reveal steroidal nuclei (triterpenes and/or steroids).

\subsection{Lippia Integrifolia DCM Extract Purification by Column Chromatography (CC)}

A total of $3 \mathrm{~g}$ of DCM extract material was loaded on a column $(54 \times 3.5 \mathrm{~cm})$ packed with Silica technical grade (pore size $60 \AA$, particle size: $63-200 \mu, 230-70$ Mesh; Sigma-Aldrich) and eluted first with $100 \%$ chloroform, then with increasing amount of EA (solvent of increasing polarity) and finally with $\mathrm{MeOH}$ (washing). One hundred and twenty fractions of $40 \mathrm{ml}$ were collected and analyzed by TLC (Silica gel 60 F254). According to the chromatographic profile, thirty-five pools were made. The solvent was evaporated under rotary evaporator until $45^{\circ} \mathrm{C}$.

\subsection{Infrared Spectrometry}

DCM extracts of four selected herbs were analyzed by infrared spectrometry by Fourier transform (FTIRPerkin Elmer Spectrum I Serie 1600) in order to determine the presence of functional groups of diagnostic value.

\subsection{Bioassays}

Two strains were used, Staphylococcus aureus F7 methicillin-resistant isolated from infected patients of a San Miguel de Tucumán hospital (Collection of Facultad de Bioquímica, Química y Farmacia, Universidad Nacional de Tucumán, Argentina), and a Pseudomonas aeruginosa ATCC 6738.

\subsection{Bacterial Growth}

Overnight cultures of $P$. aeruginosa and $S$. aureus were diluted to reach an OD of $0.125 \pm 0.01$ at $560 \mathrm{~nm}$ in Luria-Bertani (LB) and Mueller Hinton (MH) media, respectively. A $180 \mu \mathrm{l}$ aliquot of the diluted culture was placed in each one of the 96 wells of a plastic microtitre plate. 
Solutions containing 10,1 and $0.1 \mathrm{mg} / \mathrm{ml}$ extracts or fractions in a dimethyl sulfoxide and water mixture (DMSO: $\mathrm{H}_{2} \mathrm{O}, 1: 1$ ) were prepared separately, and $20 \mu \mathrm{l}$ of each solution was pipetted into the microtitre plate wells individually, with eight replicates of each solution. The final concentration of the samples assayed was 1000,100 and $10 \mu \mathrm{g} / \mathrm{ml}$ respectively. Positive control wells (eight replicates) contained $180 \mu \mathrm{l}$ of the diluted culture with $20 \mu \mathrm{l}$ of DMSO: $\mathrm{H}_{2} \mathrm{O}(1: 1)$ and negative control wells were performed using sterile culture media.

Bacterial cultures were carried out in LB and $\mathrm{MH}$ media at $37^{\circ} \mathrm{C}$. The bacterial growth was detected as the turbidity at $560 \mathrm{~nm}$ using a microtitre plate reader (Power Wave XS2; BioTek, Vermont, USA).

\subsection{Biofilm Formation Assay}

For biofilm quantification, a micro-method based on a protocol previously reported was employed [18] with some modifications [19].

\subsection{Effect of Lippia Integrifolia Fractions on $P$. Aeruginosa Al Production}

$P$. aeruginosa qsc 119 (reporter strain) is a mutant donated by P. Greenberg [20] unable to produce its own AHL (QS signal molecules). However, produce $\beta$ galactosidase in presence of exogenous AHL. In consequence, the $\beta$-galactosidase activity is proportional to the $\mathrm{AHL}$ concentration present in the supernatant obtained from P. aeruginosa ATCC 27853 cultured in LB media containing the fractions obtained from DCM extract of $L$. integrifolia. To determine the overall $\mathrm{Al}$ production in each condition, the control wells contained cell-free culture supernatant $(100 \mu \mathrm{l})$ obtained from $P$. aeruginosa ATCC 27853 cultured in LB media $(190 \mu \mathrm{l})$ plus $10 \mu \mathrm{l}$ of DMSO: $\mathrm{H}_{2} \mathrm{O}(1: 1)$. $\beta$ galactosidase activity was measured spectrophotometrically by Miller test [22]. The experiments were repeated independently three times with six replicates.

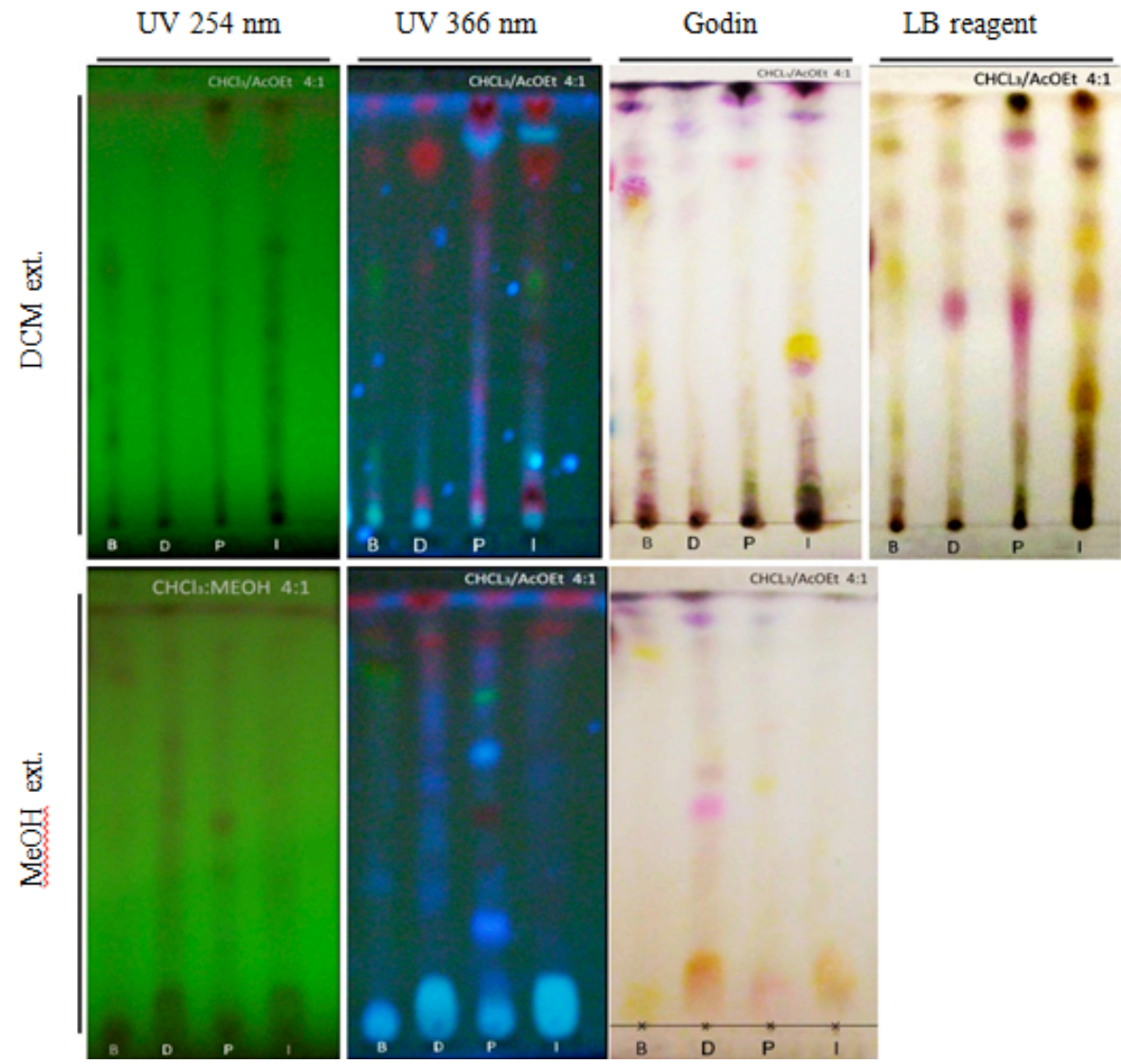

Figure 1: Chromatography profile of plant extracts. Plants were extracted with dichloromethane and methanol, and then chromatographed as described in 2.3. The chromatograms were developed with UV (at $254 \mathrm{~nm}$ and $366 \mathrm{~nm}$ ), Godin and Lieberman-Bouchard (LB) reagents. For each lane, the amount applied to the TLC plate corresponds to the minimum detectable amount. Abbreviations: (DCM ext.) dichloromethane extract, (MeOH ext.) methanol extract, (B) H. baylahuen, (D) A. deserticola, (P) S. parvifolia and (I) L. integrifolia. $\mathrm{CHCl}_{3}$ : chloroform, AcOEt: ethyl acetate, $\mathrm{MeOH}$ : methanol. 


\section{RESULTS AND DISCUSSION}

\subsection{Extraction Yields}

The choice of extraction conditions is a critical step for research of natural bioactive compounds [23]. Two extractive forms were assayed to select the best solvent and experimental conditions. Samples (200 g of each herb) extracted with DCM showed the best recovery rate of $A$. deserticola and $H$. baylahuen: 23,27 $\mathrm{g}(12 \%)$ and $36,72 \mathrm{~g}(18 \%)$; compare with the $\mathrm{MeOH}$ extraction: $18,95 \mathrm{~g}$ (9\%) and $21,46 \mathrm{~g}$ (11\%), respectively.

On the other hand, for $L$. integrifolia and $S$. parvifolia the $\mathrm{MeOH}$ extraction yields $[19,83 \mathrm{~g}(10 \%)$ and $20,19 \mathrm{~g}(10 \%)]$ were higher than DCM extraction yields $[7,52 \mathrm{~g}(3 \%)$ and $4,19 \mathrm{~g}(2 \%)$, respectively]. These results indicate the higher amount of polar components present in the $L$. integrifolia and $S$. parvifolia with respect to $A$. deserticola and $H$. baylahuen.

\subsection{Characterization of Chemical Compounds}

A TLC was developed for the $\mathrm{MeOH}$ and $\mathrm{DCM}$ extracts of the four herbs studied: A. deserticola, $H$. baylahuen, $L$. integrifolia and $S$. parvifolia. The chromatographic profiles show that all extracts are complex samples (Figure 1). The different eluates resulting mixture, have a wide range of polarities about cholesterol, taken as a reference compound. To improve the characterization in all herbs infrared spectrometry properties were screened in DCM extracts. In the spectra, diagnostic value signals at $3300,2925,1735,1380 \mathrm{~cm}^{-1}$ were observed corresponding to the stretching of $\mathrm{OH}, \mathrm{CH}$ sp3 bonds, $\mathrm{C}=\mathrm{O}$ tension and methyl groups bending, respectively. The signals between 900 and $800 \mathrm{~cm}^{-1}$ correspond to C-O stretching links (Figure 2).

The TLC results suggest that $A$. deserticola possesses a complex composition and differ with respect to its essential oil that had $95 \%$ of thujone [24]. In hydroalcoholic extracts of $A$. deserticola the presence of phenolic compounds (non flavonoids, flavonoids and tannins), saponins and triterpenes/ steroids, with anti-inflammatory was previously reported [25].

Previous works in aerial parts of $H$. baylahuen revealed the presence of anthraquinone glycosides as emodin or chrysophanic acid, flavonoids, coumarins as

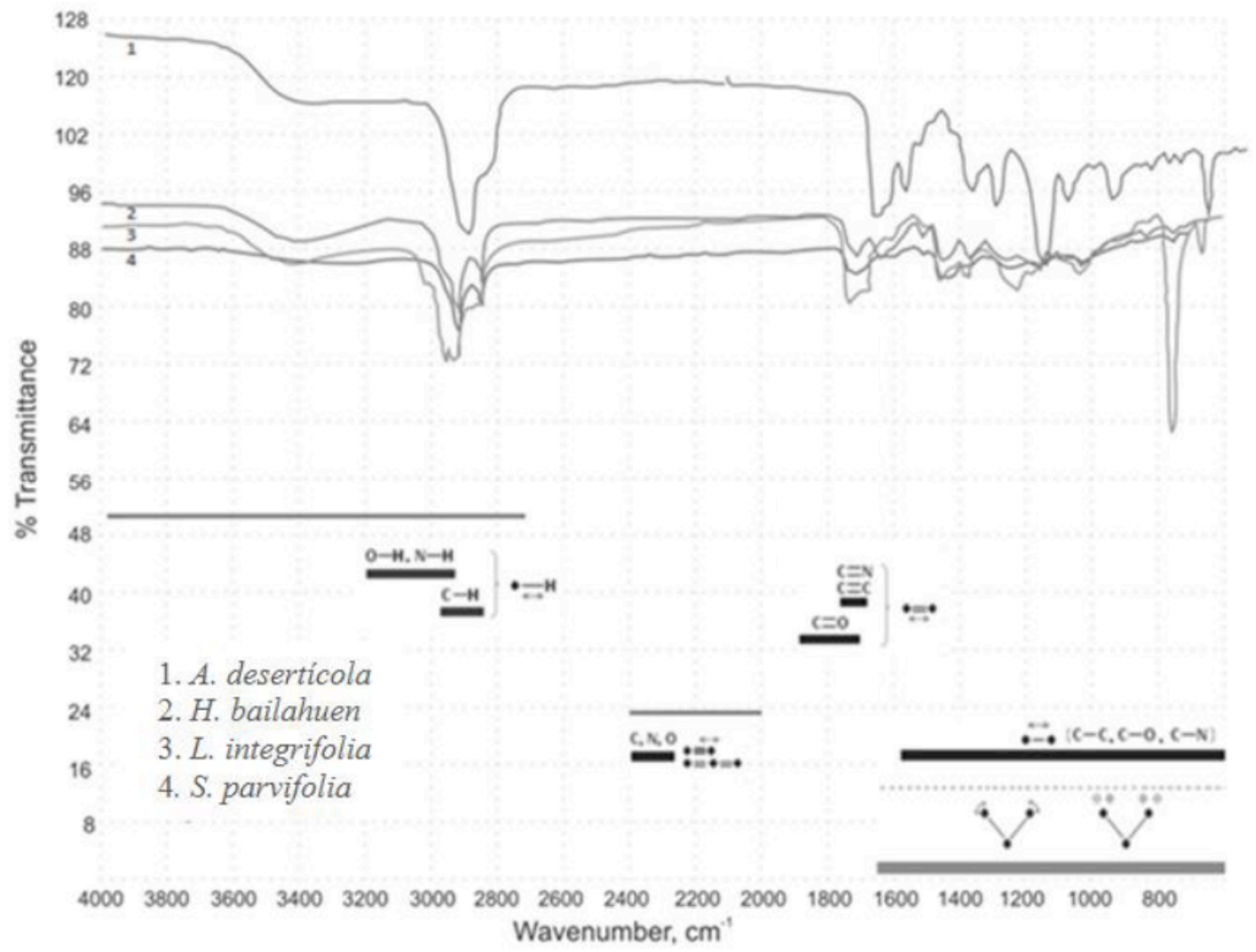

Figure 2: Infrared spectra of L. integrifolia, S. parvifolia, A. deserticola and $H$. baylahuen, in selected spectral range $4000-600 \mathrm{~cm}^{-1}$. 
esculetin, eupatilina [26], preniletina, haplopine and haplopinol [27]. The characteristic compounds of this genus are flavones, flavonols, flavonoids glycosides, some diterpenes and coumarins [28]. From Haplopappus multifolius some compounds (preniletin and haplopine) with antibacterial activity against $S$. aureus were previously informed [27].

Through a literature review, we can see that gender Lippia has been very little studied, except for the essential oils [29]. Iridoids are secondary metabolites found in this gender and have several properties as sedative, antipyretic, skin diseases, antimicrobial activity and hepatoprotective $[30,31]$.

Reports on the chemical composition of S. parvifolia indicate its essential oil composition [32, 33]. Serialized extracts in petroleum ether, $\mathrm{DCM}$ and $\mathrm{MeOH}$, obtained from the aerial parts of Muña- Muña showed antimicrobial activity against Escherichia coli and Trichophyton mentagrophytes [34]. Antimicrobial activity of flavonoids contained in Muña-Muña among other medicinal plants of Tafí del Valle, Tucuman, Argentina was also reported [35]. Most of the identified compounds were flavonoids mono- and dihydroxylated.

In all the extracts the presence of pink, purple and yellow spots observed using the Lieberman-Buchard revelator suggest the presence of triterpene and steroids with low polarity.

\subsection{Antibacterial Activity of Herbal Extracts}

None of the extracts exhibits significant inhibition of bacterial growth at low concentrations (data not shown). At the highest concentration assayed (1000 $\mu \mathrm{g} / \mathrm{ml}$ ) both extracts of $A$. deserticola diminished the bacterial growth of $S$. aureus more than $85 \%$. In the same challenge all extracts of $H$. baylahuen and $L$. integrifolia inhibited near to $45 \%$ the bacterial growth. The $\mathrm{MeOH}$ extract of S. parvifolia inhibited $36 \%$ the bacterial growth and the DCM extract decreased it by $45 \%$ (Figure 3 ).

The $P$. aeruginosa growth inhibition observed with $1000 \mu \mathrm{g} / \mathrm{ml}$ of $\mathrm{MeOH}$ and DCM extracts was 5 and $52 \%$ for $A$. deserticola, respectively; 40 and $100 \%$ for

\section{$\mathrm{MeOH}$ ext.}
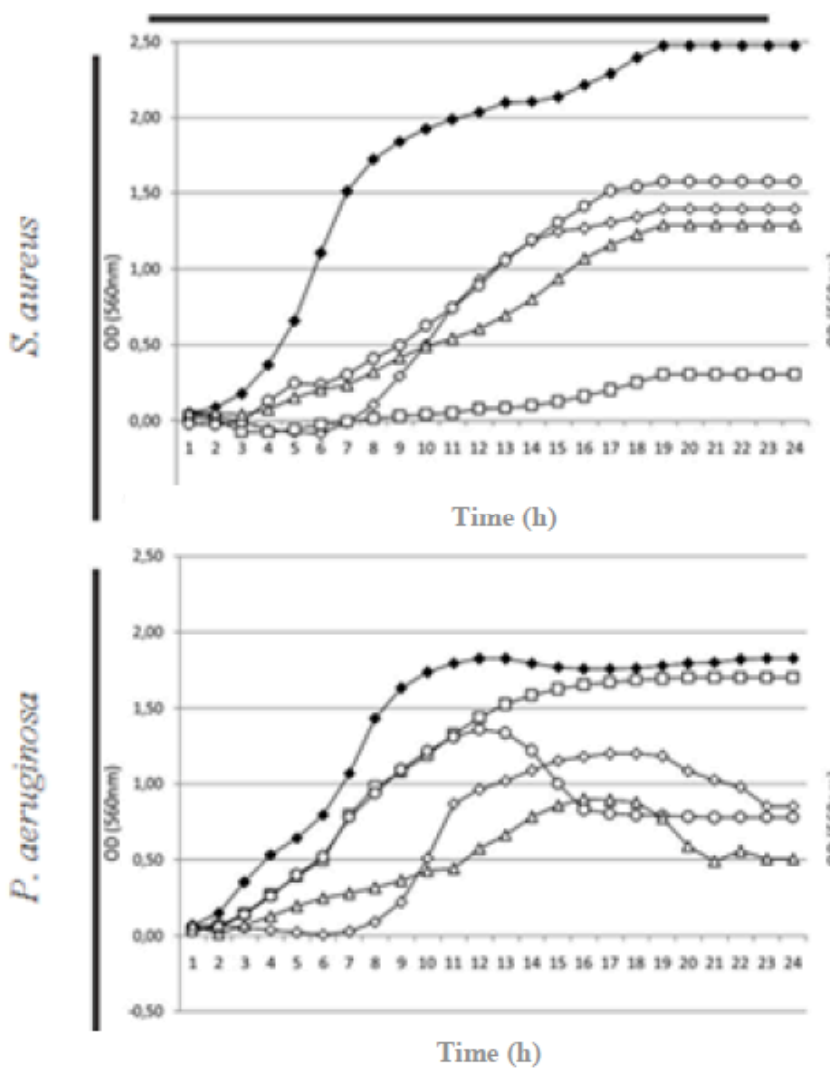

DCM ext.
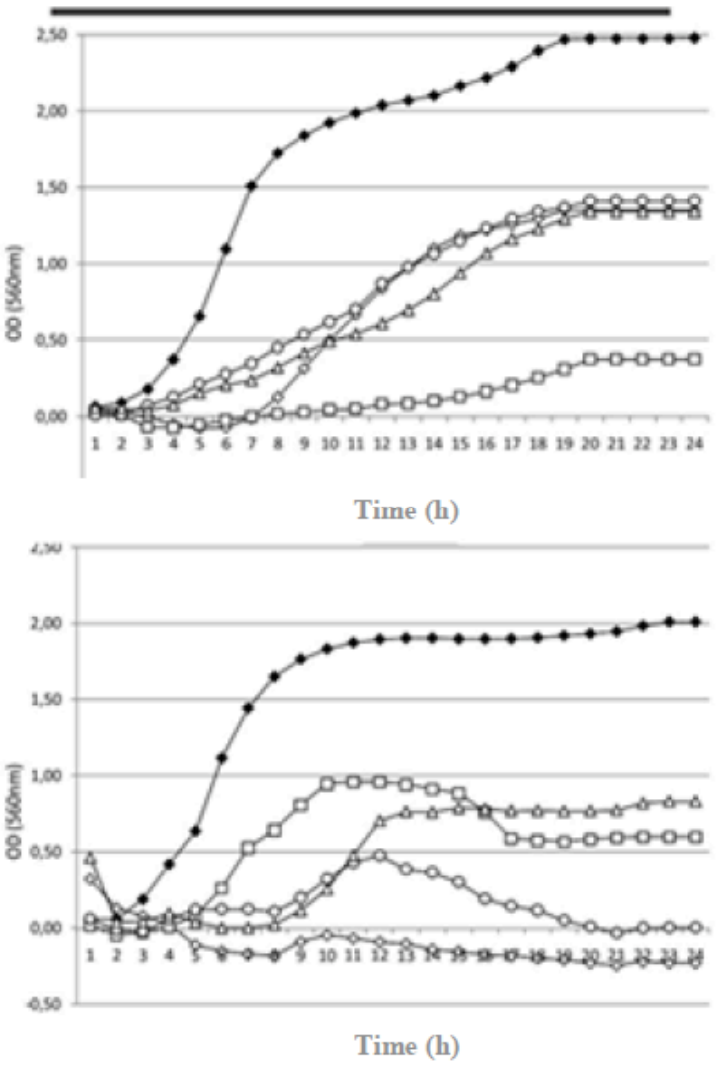

Figure 3: $S$. aureus and $P$. aeruginosa growth inhibition by $A$. deserticola $(\square), H$. baylahuen $(\diamond), L$. integrifolia $(\Delta)$ and $S$. parvifolia $(\circ)$ extracts $(1000 \mu \mathrm{g} / \mathrm{ml})$. Control without extract $(\diamond)$. (DCM ext.) dichloromethane extract, (MeOH ext.) methanol extract. 
H. baylahuen; 67 and $60 \%$ for L. integrifolia, and 56 and $81 \%$ for S. parvifolia, respectively (Figure 3 ).

The $\mathrm{MeOH}$ and DCM extracts of $A$. deserticola showed the highest percentage of inhibition of $S$. aureus bacterial growth. It is noteworthy that there were no previous reports on the antimicrobial effect $A$. deserticola on bacteria. On the other hand, the DCM extract of $H$. baylahuen suppressed completely the $P$. aeruginosa growth.

The inhibitory effect of genus Lippia against many Gram-positive bacteria was previously reported [29, 36]. In addition, Lippia essential oils have been widely shown to exhibit antimicrobial activity against other organisms [37]. Several extracts of $S$. parvifolia obtained from the aerial parts showed antimicrobial activity against $E$. coli [34].

\subsection{Influence of Herbal Extracts in Biofilm Formation}

The growth inhibitory effect was achieved at an extract concentration so higher to be considered as antimicrobials. However, at a concentration 100 times lower, the extracts showed anti pathogenic properties. The results of the influence of $\mathrm{MeOH}$ and DCM extracts from A. deserticola, $H$. baylahuen, $L$. integrifolia and $S$. parvifolia on biofilm formation by $P$. aeruginosa and $S$. aureus are shown in Figure 4.

A. deserticola inhibit the biofilm formation by $S$. aureus 87 and $45 \%$ at a concentration of $10 \mu \mathrm{g} / \mathrm{ml}$ of $\mathrm{DCM}$ and $\mathrm{MeOH}$ extracts, respectively. While for the Gram negative bacterium, $P$. aeruginosa, the inhibition was 74 and $85 \%$, respectively.

The DCM and $\mathrm{MeOH}$ extracts of $H$. baylahuen (10 $\mu \mathrm{g} / \mathrm{ml}$ ) inhibited $S$. aureus biofilm formation, 74 and $56 \%$, respectively and $P$. aeruginosa biofilm formation 70 and $92 \%$, respectively.

In presence of $L$. integrifolia $\mathrm{DCM}$ and $\mathrm{MeOH}$ extracts, the biofilm formation by $S$. aureus decreased 65 and $52 \%$, respectively. Of all samples assayed, the highest $P$. aeruginosa biofilm inhibition was observed for L. integrifolia with 98 and $93 \%$ decrease for DCM and $\mathrm{MeOH}$ extracts.

The incubation in presence of $\mathrm{DCM}$ and $\mathrm{MeOH}$ extract of $S$. parvifolia affect the biofilm formation of $S$. aureus by 68 and 35\%, respectively. On $P$. aeruginosa the inhibition these extracts was 49 and $54 \%$, respectively.

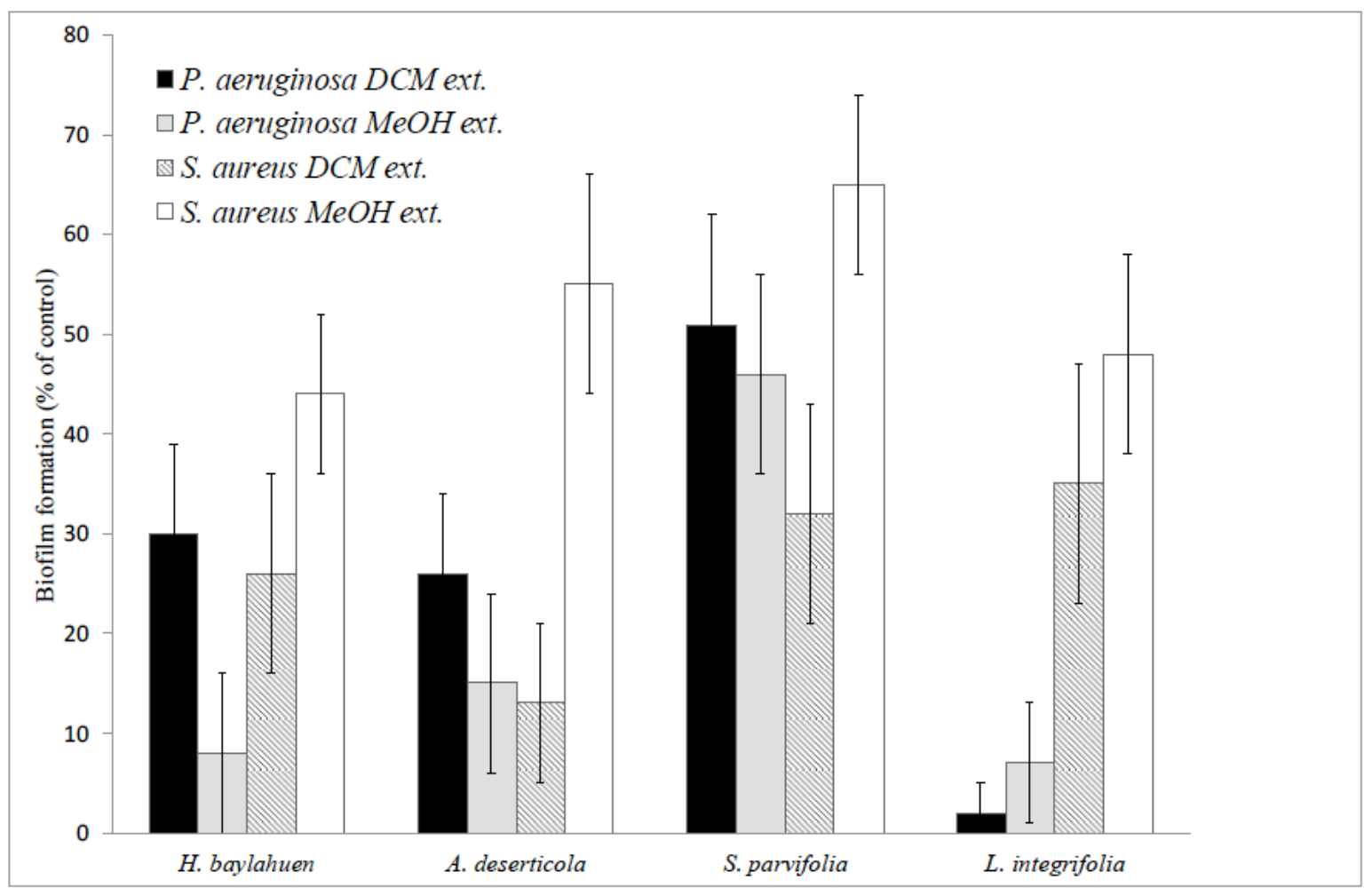

Figure 4: Inhibitory effect of $A$. deserticola, H. baylahuen, L. integrifolia and S. parvifolia extracts $(10 \mu \mathrm{g} / \mathrm{ml})$ on biofilm formation by $P$. aeruginosa and $S$. aureus. The inhibitory effect was expressed as percentage referred to the control without extract (100 \%). Abbreviations: (DCM ext.) dichloromethane extract, (MeOH ext.) methanol extract. 
To our knowledge, there are no data about $P$. aeruginosa and $S$. aureus biofilm inhibition caused by these plant species, so this work is the first report of it. Due to the high ability of $L$. integrifolia DCM extract to inhibit the biofilm formation of both strains, with emphasis on $P$. aeruginosa biofilm inhibition, this extract was chosen and processed by column chromatographic to found the active fractions.

\subsection{Column Chromatographic of L. Integrifolia}

The DCM extract of $L$. integrifolia was chemically processed as mentioned in material and methods. One hundred twenty fractions were collected and analyzed by TLC. The eluates that showed the same TLC profiles were pooled in 35 fractions (Table 1; Figure 5).

Table 1: Bioactivity Detected in Lippia Integrifolia DCM Extract and Chromatographic Fractions (F). The Inhibitory Effect was Express as Percent of Control (Raw Sample)

\begin{tabular}{|c|c|c|c|}
\hline $\begin{array}{l}\text { Sample } \\
10 \mu \mathrm{g} / \mathrm{ml}\end{array}$ & \multicolumn{3}{|c|}{ Inhibition of Pseudomonas Aeruginosa (\%) } \\
\hline Crude Extract & 14 & 98 & 78 \\
\hline F1 - EA: C (5:95) & 22 & 77 & 68 \\
\hline F12 - EA: C (5:95) & 20 & 69 & 44 \\
\hline F25 - EA: C (5:95) & 10 & 78 & 17 \\
\hline F27 - EA: C (5:95) & 33 & 58 & 55 \\
\hline F30 - EA: C (5:95) & 30 & 39 & 28 \\
\hline F33 - EA: C (5:95) & 20 & 86 & 77 \\
\hline F35 - EA: C (15:85) & 24 & 100 & 84 \\
\hline F38 - EA: C (15:85) & 37 & 93 & 3 \\
\hline F48 - EA: C (15:85) & 92 & 79 & 20 \\
\hline F53 - EA: C (15:85) & 89 & 75 & 51 \\
\hline F56 - EA: C (20:80) & 89 & 71 & -3 \\
\hline F57 - EA: C (20:80) & 91 & 86 & -11 \\
\hline F58 - EA: C (20:80) & 95 & 82 & 70 \\
\hline F60 - EA: C (20:80) & 72 & 73 & 17 \\
\hline F63 - EA: C (20:80) & 96 & 38 & -113 \\
\hline F64 - EA: C (20:80) & 60 & 81 & 92 \\
\hline F68 - EA: C (20:80) & 88 & 98 & 85 \\
\hline F102 - EA: C (50:50) & 28 & 99 & 76 \\
\hline F106 - EA: C (70:30) & 36 & 79 & 81 \\
\hline F108 - EA: C (70:30) & 29 & 99 & 82 \\
\hline F111 - EA: C (70:30) & 36 & 97 & 86 \\
\hline F115 - EA: C (70:30) & 93 & 86 & 81 \\
\hline F118 - EA: C (70:30) & 69 & 67 & 89 \\
\hline F119 - EA: C (70:30) & 51 & 88 & 80 \\
\hline F120 - EA: C (70:30) & 53 & 94 & 61 \\
\hline
\end{tabular}

Abbreviation: (EA) ethyl acetate, (C) chloroform. 
$5 \%-10 \%$ AcOEt

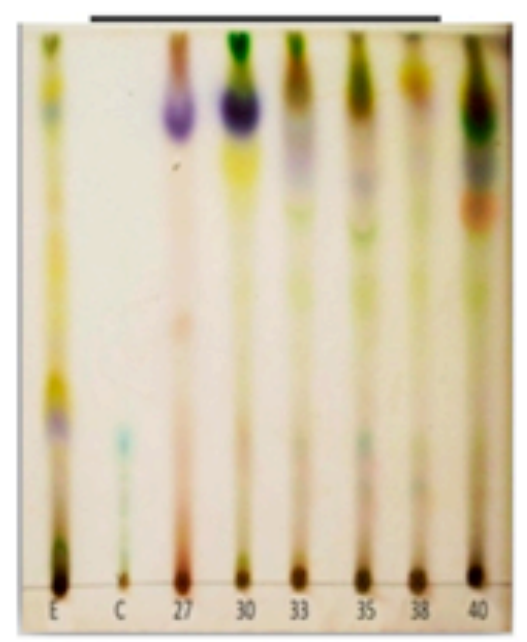

$50 \% \mathrm{AcOEt}$

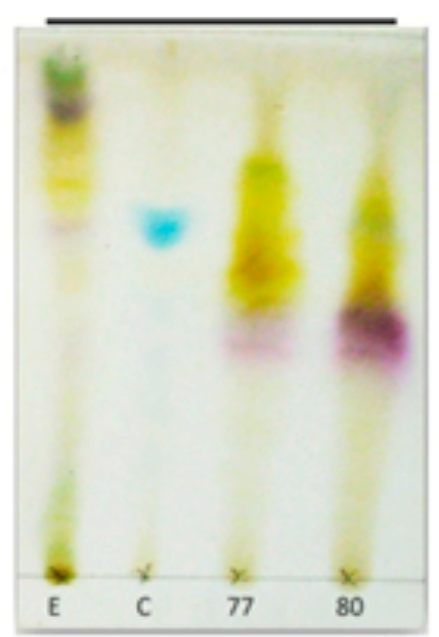

$15 \%-20 \% \mathrm{AcOEt}$

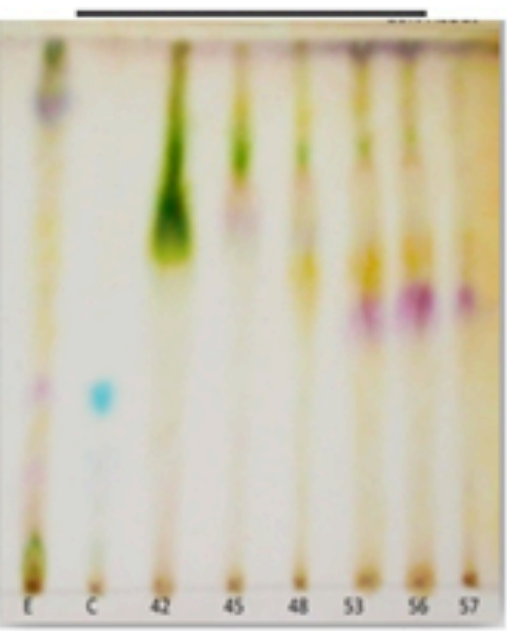

$70 \% \mathrm{AcOEt}$

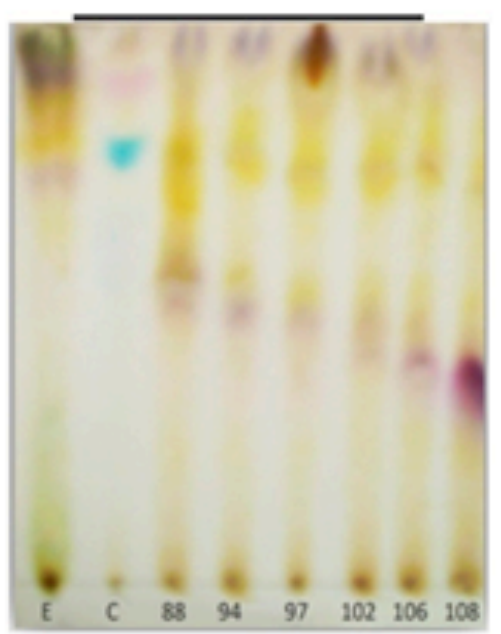

\section{$20 \%-40 \%$ AcOEt}

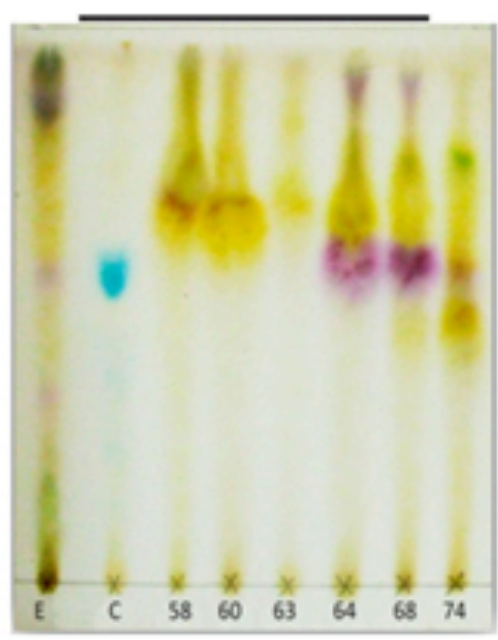

\section{$100 \% \mathrm{AcOEt}$}

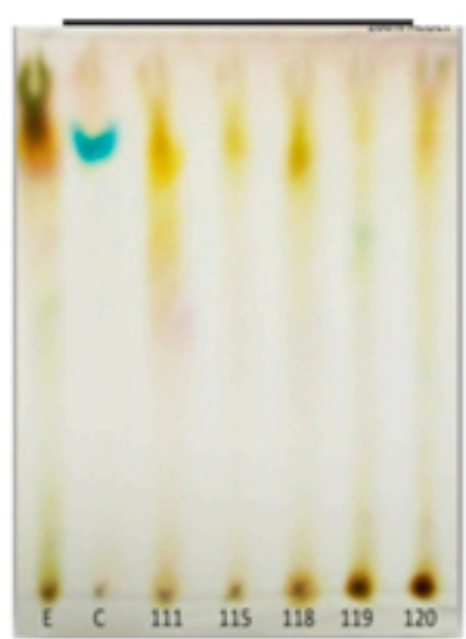

Figure 5: TLC bioassay of $L$. integrifolia fractions. Fractions were obtained as described in 2.4. The chromatograms were developed with Lieberman-Bouchard (LB) reagent. For each lane, the amount applied to the TLC plate corresponds to the minimum detectable amount. Abbreviation: (E) L. integrifolia crude extract, (C) cholesterol. AcOEt: ethyl acetate.

The fractions were tested for growth, biofilm and autoinducers inhibition of $P$. aeruginosa (Table 1).

According to the polarity of the fractions, different inhibitory effects were observed on $P$. aeruginosa (Table 1). The total extracts of $L$. integrifolia, not showed a notable antibacterial effect against $S$. aureus and $P$. aeruginosa at the tested concentrations thereof. However, several column fractions of DCM extract showed an inhibition greater than $80 \%$ for $P$. aeruginosa growth. The eluate 26 (F26) obtained with $5 \%$ EA and $95 \%$ C, inhibited $87 \%$ the bacterial growth. And almost all the fractions that elute with $20 \%$ EA and $80 \%$ C inhibited more than $80 \%$ the bacterial development, showing several of them a purple band with a retention factor (Rf) between 0.5 and 0.75 (Figure 5). A good correlation was observed between bacterial growth and biofilm inhibition for the fractions above mentioned, with the exception of the fraction 63 that inhibit less the biofilm.

On the other hand, it is well known that several compounds are able to modify the biofilm formation by inhibiting the autoinducers production and without altering the bacterial development. Antipathogenic compounds do not kill bacteria or stop their growth. They rather control bacterial virulence factors and prevent the development of resistant strains [38]. The available data indicate that plants might produce a wide range of Al-inhibitory compounds [39]. Anti-QS activity has been shown in a few terrestrial plants [40, 41,42]. In addition, the influence of few secondary metabolites from South American plants on biofilm formation has been reported by our laboratory [41, 43, 44, 45, 46]. 
Moreover, several food components such as honey [47], Zuccagnia punctata [48] or citrus essential oil [19] are able to inhibit $P$. aeruginosa biofilm.

Since our results demonstrated that many fractions of $L$. integrifolia inhibit the biofilm formation, we wanted to know how the influence in the overall production of QS signals is. To investigate if the activation of the QS systems takes place during the biofilm formation a quantification of the overall Al production was carried out in each chromatographic condition during the biofilm formation experiments on microtitre plates using $P$. aeruginosa.

In this way, we found several fractions that inhibit the biofilm formation without modify the bacterial growth, such as the less polar fraction 33 and 35 , as well as, almost all the fractions that elute with EA:C (50:50) and (70:30). A similar behavior was observed for the crude extract of $L$. integrifolia (Table 1 ).

The biofilm inhibition could be due to the lower bacterial growth or because the lower Al production. In general, the lower polar fractions inhibited biofilm in correlation with bacterial growth. However, in more polar fractions the biofilm diminution is well correlated with the inhibition of $\mathrm{Al}$ production more than the bacterial development. These results suggest different mode of actions of the fractions studied. An important point to emphasize is that at not-inhibitory-growthconcentrations the biofilm is inhibited, indicating an antipathogenic effect of some extracts and fractions, rather than an antibacterial effect.

\section{CONCLUSION}

The extracts of $A$. deserticola, $H$. baylahuen, $L$. integrifolia and $S$. parvifolia, exhibited anti-pathogenic properties by inhibiting the growth and biofilm formation by $S$. aureus and $P$. aeruginosa. The DCM extract of $L$. integrifolia presented many fractions with stronger inhibitory activity of $P$. aeruginosa growth, biofilm and autoinducer production. This study demonstrated that these plant species traditionally consumed as infusions in mate may be the responsible for the protection against foodborne diseases when this drink is socially ingested.

\section{ACKNOWLEDGEMENTS}

The authors thank ANCyT Argentina (PICT $2011 \mathrm{~N}^{\circ}$ 1202) and PIUNT 552-1 for their grants.

\section{CONFLICT OF INTEREST}

The authors declare that there is no conflict of interest related to this work.

\section{REFERENCES}

[1] Bracesco N, Sánchez AG, Contreras V, Menini $T$ and Gugliucci A. Recent advances on Ilex paraguariensis research: Minireview. J Ethnopharmacol 2011; 136: 378-384. https://doi.org/10.1016/j.jep.2010.06.032

[2] Heck Cl and de Mejia EG. Yerba Mate Tea (Ilex paraguariensis): a comprehensive review on chemistry, health implications, and technological considerations. J Food Sci 2007; 72: 138-151. https://doi.org/10.1111/j.1750-3841.2007.00535.x

[3] Filip R, Lopez P, Giberti G, Coussio J and Ferraro G. Phenolic compounds in seven South American Ilex species. Fitoterapia 2001; 72: 774-778.

https://doi.org/10.1016/S0367-326X(01)00331-8

[4] Filip R, Ferraro GE, Bandoni AL, Bracesco N, Nunes E Gugliucci A, et al. Mate (Ilex Paraguariensis). Recent Advances in Phytochemistry, Imperato, F., Ed.; Editorial Research Signpost: Kerala, India, 2009; pp. 113-131.

[5] Gagliardi F. La higiene del mate, ese compa-ero lleno de bacterias. 2013 Internet: (accessed May 24, 2017).

[6] Usach, Z. Compartir el mate aumenta el riesgo de contraer infecciones. Los Andes. 2013 (accessed May 24, 2017).

[7] Isolabella S, Cogoi L, López P, Anesini C, Ferraro G and Filip $R$. Study of the bioactive compounds variation during yerba mate (Ilex paraguariensis) processing. Food Chem 2010; 122: 695-699.

https://doi.org/10.1016/j.foodchem.2010.03.039

[8] Morales G, Paredes A, Sierra P and Loyola LA. Antioxidant activity of $50 \%$ aqueous ethanol extract from Acantholippia deserticola. Biol Res 2008; 41: 151-155. https://doi.org/10.4067/S0716-97602008000200004

[9] Vogel H, Gonzalez M, Faini F, Razmilic I, Rodríguez J, Martin JS, et al. Antioxidant properties and TLC characterization of four Chilean Haplopappus-species known as bailahuen. J Ethnopharmacol 2005; 97: 97-100. https://doi.org/10.1016/j.jep.2004.10.027

[10] Marcial G, Sendker J, Brandt S, de Lampasona MP, Catalan $\mathrm{CA}$, de Valdez GF, et al. Gastroprotection as an example: antiadhesion against Helicobacter pylori, anti-inflammatory and antioxidant activities of aqueous extracts from the aeria parts of Lippia integrifolia Hieron. J Ethnopharmacol 2014; 155: $1125-1133$.

https://doi.org/10.1016/j.jep.2014.06.039

[11] Cabana R, Silva LR, Valentão $\mathrm{P}$, Viturro $\mathrm{Cl}$ and Andrade PB. Effect of different extraction methodologies on the recovery of bioactive metabolites from Satureja parvifolia (Phil.) Epling (Lamiaceae). Ind Crop Prod 2013; 48: 49-56. https://doi.org/10.1016/j.indcrop.2013.04.003

[12] Srey S, Jahid IK and $\mathrm{Ha}$ SD. Biofilm formation in food industries: A food safety concern. Food Control 2013; 31; 572-585.

https://doi.org/10.1016/j.foodcont.2012.12.001

[13] Bassler BL and Losick R. Bacterially speaking. Cell 2006; 125: $237-246$.

https://doi.org/10.1016/j.cell.2006.04.001

[14] Gram L, Ravn L, Rasch M, Bruhn JB, Christensen AB and Givskov M. Food spoilage interactions between food spoilage bacteria. Int J Food Microbiol 2002; 78: 79-97. https://doi.org/10.1016/S0168-1605(02)00233-7

[15] Telford G, Wheeler D, Williams P, Tomkins PT, Appleby P, Sewell $\mathrm{H}$, et al. The Pseudomonas aeruginosa quorum- 
sensing signal molecule $\mathrm{N}$-(3-oxododecanoyl)-I-homoserine lactone has immunomodulatory activity. Infect Immun 1998; 66: 36-42.

[16] Rode TM, Langsrud S, Holck A and Moretro T. Different patterns of biofilm formation in Staphylococcus aureus under food-related stress conditions. Int J Food Microbiol 2007; 116: 372-383.

https://doi.org/10.1016/j.ijfoodmicro.2007.02.017

[17] Godin P. A new spray reagent for paper chromatography of polyols and cetoses. Nature 1954; 174: 134-134. https://doi.org/10.1038/174134a0

[18] O'Toole GA and Kolter R. Initiation of biofilm formation in Pseudomonas fluorescens WCS365 proceeds via multiple, convergent signalling pathways: a genetic analysis. Mol Microbiol 1998; 28: 449-461. https://doi.org/10.1046/j.1365-2958.1998.00797.x

[19] Luciardi MC, Blázquez MA, Cartagena E, Bardón A and Arena ME. Mandarin essential oils inhibit quorum sensing and virulence factors of Pseudomonas aeruginosa. Food Sci Tech 2016b; 68: 373-380 https://doi.org/10.1016/j.Iwt.2015.12.056

[20] Whiteley M, Lee KM and Greenberg EP. Identification of genes controlled by quorum sensing in Pseudomonas aeruginosa. In Proceedings of the National Academy of Sciences of the United States of America, Washington, USA, 1999, 96, pp. 13904-13909

https://doi.org/10.1073/pnas.96.24.13904

[21] Miller MB and Bassler BL. Quorum sensing in bacteria. Annu Rev Microbiol 2001; 55: 165-199. https://doi.org/10.1146/annurev.micro.55.1.165

[22] Miller JH. Experiments in molecular genetics. Cold Spring Harbor. New York: Cold Spring Harbor Laboratory 1972.

[23] Tura D and Robards K. Sample handling strategies for the determination of biophenols in food and plants. J Chromatogr A 2002; 975: 71-93. https://doi.org/10.1016/S0021-9673(02)00879-8

[24] Rojo LE, Benites J, López J, Rojas M, Díaz P, Ordó-ez J, et al. Antioxidant capacity and polyphenolic content of twelve traditionally used herbal medicinal infusions from the South American Andes. BLACPMA 2009; 8: 498-508.

[25] Torres-Carro R, Isla MI, Ríos J.L, Giner RM and Alberto MR. Anti-inflammatory properties of hydroalcoholic extracts of Argentine Puna plants. Food Res Int 2015; 67: 230-237 https://doi.org/10.1016/j.foodres.2014.11.012

[26] Silva $M$ and Sammes PG. A new diterpenic acid and other constituent of Haplopappus foliosus and $\mathrm{H}$. Angustifolius. Phytochemistry 1973; 12: 1755-1758. https://doi.org/10.1016/0031-9422(73)80397-8

[27] Chiang MT, Bittner M, Silva M, Mondaca A, Zemelman R and Sammes PG. A prenylated coumarin with antimicrobial activity from Haplopappus multifolius. Phytochemistry 1982; 21: $2753-2755$ https://doi.org/10.1016/0031-9422(82)83119-1

[28] Urzúa A, Torres R, Mu-oz $\mathrm{M}$ and Palacios $\mathrm{Y}$. Comparative antimicrobial study of the resinous exudates of some Chilean Haplopappus (Asteraceae). J Ethnopharmacol 1995; 45: 7174

https://doi.org/10.1016/0378-8741(94)01196-7

[29] Pascual ME, Slowing K, Carretero E, Sánchez Mata D and Villar A. Lippia: traditional uses, chemistry and pharmacology: a review. J Ethnopharmacol 2001; 76: 201214

https://doi.org/10.1016/S0378-8741(01)00234-3

[30] Kondo $\mathrm{Y}$, Takano $\mathrm{F}$ and Hojo H. Suppression of chemically and immunologically induced hepatic injuries by gentiopicroside in mice. Planta Med 1994; 60: 414-416. https://doi.org/10.1055/s-2006-959521

[31] Liu J, Liu Y and Klaassen CD. (1994). The effect of Chinese hepatoprotective medicines on experimental liver injury in mice. J Ethnopharmacol 1994; 42: 183-191. https://doi.org/10.1016/0378-8741(94)90084-1

[32] Muschietti L, Van Baren C, Coussio J, Vila R, Clos M, Caigueral S, et al. Chemical composition of the leaf oil of Satureja odora and Satureja parvifolia. J Essent Oil Res 1996; 8: 681-684.

https://doi.org/10.1080/10412905.1996.9701042

[33] Viturro Cl, Molina A, Guy I, Charles B, Guinaudeau H and Fournet A. Essential oils of Satureja boliviana and Satureja parvifolia growing in the region of Jujuy, Argentina. Flavour Fragr J 2000; 15: 377-382.

https://doi.org/10.1002/1099-1026(200011/12)15:6<377::AIDFFJ926>3.0.CO;2-P

[34] Feresin GE, Tapia A, López SN and Zacchino SA Antimicrobial activity of plants used in traditional medicine of San Juan province, Argentine. J Ethnopharmacol 2001; 78 : 103-107.

https://doi.org/10.1016/S0378-8741(01)00322-1

[35] Hernández NE, Tereschuk ML and Abdala LR. Antimicrobia activity of flavonoids in medicinal plants from Tafí del Valle (Tucuman, Argentina). J Ethnopharmacol 2000; 73: 317-322. https://doi.org/10.1016/S0378-8741(00)00295-6

[36] Muschietti L, Derita M, Sulsen V, de Dios Munoz J, Ferraro $\mathrm{G}$, Zacchino $\mathrm{S}$, et al. In vitro antifungal assay of traditional Argentine medicinal plants. J Ethnopharmacol 2005; 102 233-238.

https://doi.org/10.1016/j.jep.2005.06.017

[37] Lemos TLG, Matos FJA, Alencar JW, Craveiro AA, Clark AM and Mc Chesney JD. Antimicrobial activity of essential oils of Brazilian plants. Phytother Res 1990; 4: 82-84. https://doi.org/10.1002/ptr.2650040210

[38] Otto M. Quorum-sensing control in Staphylococci a target for antimicrobial drug therapy? FEMS Microbiol Lett 2004; 241: 135-141.

https://doi.org/10.1016/j.femsle.2004.11.016

[39] Rice SA, McDougald D, Kumar N and Kjelleberg S. The use of quorum-sensing blockers as therapeutic agents for the control of biofilm-associated infections. Curr Opin Invest Dr 2005; 6: 178-184.

[40] Gao M, Teplitski M, Robinson JB and Bauer WD. Production of substances by Medicago truncatula that affect bacterial quorum sensing. Mol Plant Microbe Interact 2003; 16: 827834.

https://doi.org/10.1094/MPMI.2003.16.9.827

[41] Gilabert $M$, Ramos AN, Schiavone MM, Arena ME and Bardon A. Bioactive sesqui- and diterpenoids from the Argentine liverwort Porella chilensis. J Nat Prod 2011; 74: 574-579.

https://doi.org/10.1021/np100472d

[42] Teplitski M, Robinson JB and Bauer WD. Plants secrete substances that mimic bacterial $\mathrm{N}$-acyl homoserine lactone signal activities and affect population density-dependent behaviors in associated bacteria. Mol Plant Microbe Interact 2000; 13: 637-648. https://doi.org/10.1094/MPMI.2000.13.6.637

[43] Amaya S, Pereira JA, Borkosky SA, Valdez JC, Bardón A and Arena ME. Inhibition of quorum sensing in Pseudomonas aeruginosa by sesquiterpene lactones. Phytomedicine 2012; 19: 1173-1177.

\section{https://doi.org/10.1016/j.phymed.2012.07.003}

[44] Gilabert M, Cartagena E, Escobar G, Bardón A and Arena ME. Volatile terpenoids from water Pepper (Polygonum punctatum) against Pseudomonas aeruginosa and Staphylococcus aureus virulence strategies. Glob J Agric Innov Res Dev 2014; 1: 3-10.

https://doi.org/10.15377/2409-9813.2014.01.01.1

[45] Socolsky C, Arena ME, Asakawa $Y$ and Bardon A Antibacterial prenylated acylphloroglucinols from the fern Elaphoglossum yungense. J Nat Prod 2010; 73: 1751-1755. https://doi.org/10.1021/np1001779 
[46] Luciardi MC, Pérez Hernández MV, Muruaga N, Bardón A, Arena ME and Cartagena E. Volatiles from subtropical Convolvulaceae that interfere with bacterial cell-to-cell communication as potential antipathogenic drugs. EvidBased Compl Alt 2016a. (accessed May 24, 2017).

[47] Al-Nahari AAM, Almasaudi SB, El-Ghany EMA, Barbour E, Al Jaouni SK and Harakeh S. Antimicrobial activities of Saudi honey against Pseudomonas aeruginosa. Saudi J. Biol Sci
2015; 22: 521-525.

https://doi.org/10.1016/j.sjbs.2015.04.006

[48] Nuño G, Alberto MR, Arena ME, Zampini C and Isla MI. Effect of Zuccagnia punctata Cav. (Fabaceae) extract on proinflammatory enzymes and on planktonic cells and biofilm from Staphylococcus aureus. Toxicity studies. Saudi J Biol Sci 2016.

Received on 13-12-2017

Accepted on 20-12-2017

Published on 29-12-2017

DOI: http://dx.doi.org/10.15377/2409-9813.2017.04.5

(c) 2017 Mario Eduardo Arena; Avanti Publishers.

This is an open access article licensed under the terms of the Creative Commons Attribution Non-Commercial License (http://creativecommons.org/licenses/by-nc/3.0/) which permits unrestricted, non-commercial use, distribution and reproduction in any medium, provided the work is properly cited. 